Available online at

ScienceDirect

www.sciencedirect.com
Elsevier Masson France

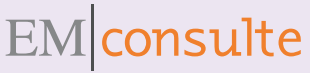

www.em-consulte.com

\title{
Animals, advance directives, and prudence: Should we let the cheerfully demented die?
}

\author{
Animaux, directives anticipées et prudence : devrions-nous laisser mourir les \\ «déments heureux»?
}

\section{D.G. Limbaugh (Ph.D Candidate)}

Department of Philosophy, University at Buffalo, 135 Park Hall, Buffalo, NY 14260, USA

Received 2 July 2016; accepted 6 October 2016

Available online 21 November 2016

\section{KEYWORDS}

Animalism;

Advance directives;

Personal identity;

Prudence;

Dementia

\begin{abstract}
Summary This paper argues that the animalist-someone who believes we are no more than human organisms - should not be highly confident that advance directives are properly applied to patients who are cheerful and yet severely demented. Pretend that I have suffered from severe dementia for some time. Though I am cheerful and well off considering the circumstances, I live with minimal psychological continuity. Currently I am sitting in a chair gazing out a window. Question: is the individual sitting in the chair actually me? My memories, hopes, fears, interests, and ability to project myself into the future are gone. Am I also gone? Now let's imagine that the individual in the chair has been diagnosed with pneumonia. I signed an advance directive refusing treatment in such a scenario. Has the individual in the chair signed an advance directive? The answer to this question depends on what you think I am and what it takes for such a thing to persist. The animalist, who tells us we are nothing more than human organisms, says that I persist if the organism persists. I survive as long as the organism survives, and that survival has nothing to do with psychology (memories, beliefs, etc.), only with biology. So, me-last-night is identical to me-this-morning if the organism is the same as it was last night. This will be true if the organism survived (remained alive) through the night. Now, I-as the signee-sign an advance directive in the interest of consenting in advance in case there is a time when I-as the patient-cannot speak for myself in terms of medical treatment. I assume that the consent in this case is binding only if I am in fact speaking for myself in the future and not someone else. That is, I must be both the signee and the patient for the advance directive to be binding. The advocate of animalism contends that her view gives the obvious answer. That the patient and signee are identical. There is no clinical case where one would be remotely tempted to apply an advance directive where the signee and patient do not share
\end{abstract}

E-mail address: dglimbau@buffalo.edu 
a life. If the signee and patient share a life, then they are the same organism, and according to animalism the signee has survived and is thus identical to the patient. So, if animalism is true, then in the case of severe dementia or Alzheimer's, the organism continues to persist, which means I continue to persist. Were this problem merely theoretical, then perhaps the above argument would be satisfying, assuming the truth of animalism. However, in practice, we need more than the assumed truth of animalism. To overcome this problem of identity, we need enough justification in animalism to warrant a lethal omission of action towards a cheerful patient who cannot express her own wishes. That is, animalism is only helpful in telling you when to honor an advance directive in so much as you are confident enough in its truth to allow for the consequences of a mistake. I assume that when it comes to the risk of allowing the wrong individual to die, we should have a high level of confidence in the success of our actions before proceeding, ceteris paribus. I argue that we should not have a high level of confidence that we persist according to animalism, and thus, we should not apply lethal advance directives to the cheerfully demented. My argument is that animalism is undermined by its attempts to overcome objections. For instance, the animalist must be able to principally exclude the brain, as opposed to the animal, as what is the thinker. There is consensus among animalist that the best way to avoid the brain as the thinker is to adopt a sparse ontology denying the existence of brains, hands, tables, and chairs. However, the adoption of such an ontology reduces the justificatory force of commonsense, which is key in arguing for animalism and that we persist as long as our animal is biologically alive. This is also a loss of justification that I am the signee and the patient, that the advance directive applies to the individual in the chair, and that the directive is sufficient to let that individual die.

(c) 2016 Elsevier Masson SAS. All rights reserved.

\author{
MOTS CLÉS \\ Animalistes ; \\ Directives \\ anticipées ; \\ Identité personnelle ; \\ Prudence ; \\ Démence
}

Résumé Cet article soutient que les animalistes-ceux qui croient que nous ne sommes que des animaux - ne devraient pas être hautement confiants que les directives anticipées sont proprement applicables aux patients qui sont heureux bien qu'atteints de démence sévère. Imaginez que j'aie souffert de démence sévère depuis un certain moment. Bien que je sois heureux et à l'aise vu les circonstances, je ne vis qu'avec une continuité psychologique minimale. En ce moment, je suis assis sur une chaise à regarder dehors. Question: est-ce que l'individu assis sur cette chaise est vraiment moi ? Mes souvenirs, espoirs, craintes, intérêts et mon habileté à me projeter dans le futur ont disparue. Ai-je également disparu ? Imaginons que l'individu sur la chaise ait été diagnostiqué pneumonique. J'ai signé une directive anticipée voulant que je ne reçoive pas de traitement dans un tel scénario. Est-ce que l'individu assis sur la chaise a signé une directive anticipée ? La réponse à cette question dépend de ce que je suis et des conditions nécessaires à la persistance. L'animaliste, qui nous assure que nous ne sommes rien d'autre que des organismes humains, affirme que nous survivons si notre organisme persiste dans l'existence. Je survis aussi longtemps que mon organisme survit et ma survivance n'a rien à voir avec ma psyché (mes souvenirs, me croyances, etc.) ; elle ne dépend que de ma biologie. Par conséquent, «moi-hier-soir » est identique à «moi-ce-matin » si et seulement si l'organisme est le même ce matin qu'hier. Cela ne sera vrai que si l'organisme est resté en vie durant la nuit. Seulement, je-le signataire-signe une directive afin de consentir à l'avance à un certain traitement dans le cas où je-le patient-ne pourrait pas parler en mon propre nom en ce qui a trait aux affaires médicales. Je présume que le consentement dans ce cas n'est contraignant que si je parle en mon nom dans le futur et non au nom de quelqu'un d'autre. C'est-à-dire que je dois être aussi bien le signataire que le patient pour que la directive anticipée soit contraignante. Le partisan de l'animalisme prétend que sa thèse nous fournit une réponse immédiate. Le patient et le signataire seraient identiques. Il n'y a aucun cas clinique où l'on serait tenté d'appliquer une directive anticipée alors que le signataire et le patient ne partagent pas la même vie. Or si le signataire et le patient partagent la même vie, ils constituent un seul et même organisme et donc, selon la thèse animaliste, le signataire aurait survécu et serait identique au patient. Conséquemment, si l'animalisme est vrai, dans le cas où je suis atteint de démence sévère ou d'Alzheimer, mon organisme continue à persister dans l'existence, ce qui veut dire que je survis. Si le problème n'avait été que théorique et en supposant que la thèse animaliste est correcte, il est possible que l'argument précédent nous eût satisfaits. Néanmoins, dans la pratique, nous avons besoin de plus que de supposer 
que l'animalisme soit vrai. Pour résoudre le problème de l'identité dans un cas particulier, nous avons besoin d'une justification assez solide en l'animalisme pour légitimer l'omission des soins nécessaires à maintenir en vie le patient heureux. Autrement dit, l'animalisme n'est utile, lorsqu'il dicte en quelles circonstances honorer les directives anticipées, que si nous sommes assez confiants dans sa vérité pour tolérer les conséquences d'une erreur. Je présume que, lorsqu'il y a une possibilité de laisser mourir le mauvais individu, nous devrions, avant de procéder, avoir le plus haut degré de confiance dans le succès de notre action, ceteris paribus. Je maintiens que nous n'avons pas de raisons suffisantes d'être pleinement confiants en la vérité de l'animalisme, et donc nous ne devrions pas suivre les directives anticipées au cas du dément heureux. Mon raisonnement est que l'animalisme est miné par ses tentatives de répondre à des objections. Par exemple, l'animaliste doit être en mesure d'exclure, par des principes, que le cerveau plutôt que l'animal soit le penseur. Il y a un consensus au sein des animalistes que le meilleur moyen d'éviter cette proposition est d'adopter une ontologie parcimonieuse qui nie l'existence des cerveaux, des mains, des tables et des chaises. En revanche, l'adoption d'une telle ontologie réduit la force justificatrice du sens commun, lequel est un élément clef dans les arguments en faveur de l'animalisme et de la thèse selon laquelle nous persistons tant et aussi longtemps que l'animal persiste biologiquement. L'adoption d'une telle ontologie se fait aussi au détriment de la force justificatrice de la thèse que je suis le signataire et le patient, de la thèse que la directive anticipée s'applique à l'individu dans le chaise ; enfin, de la thèse que la directive est suffisante pour nous permettre de laisser mourir l'individu atteint de démence. (c) 2016 Elsevier Masson SAS. Tous droits réservés.

\section{Introduction}

This paper argues that if one is an animalist-a holder of the view that we are human animals (further explained below) - then she should rethink the applicability of advance directives. That is, if one holds the view that we are identical to human organisms - the position of, to name a few, Peter van Inwagen [1], Eric Olson [2], Trenton Merricks [3], and David Hershenov [4], then lethal advance directives to "not treat" as applied to the cheerfully severally demented (e.g., some Alzheimer's patients) are suspect.

Here is the problem. If the patient is severely demented, then the animalist should lack a high level of confidence that the signee of an advance directive is (is identical to) the patient the directive might be applied to at a later time. I assume that in the case of lethal advance directives, we want to be highly confident that we let the right patient die. Thus, the animalist should not apply lethal advance directives to the severely demented.

In what follows, I will briefly explain why a highconfidence in the identity of the patient is important in applying lethal advance directives. I will then lay out the main argument for why such confidence is not had on animalism. Section three will develop this argument by demonstrating how responding to objections should cause animalists to lose confidence in their view. This loss is a result of their adopting a sparse ontology called 'biological minimalism'-the claim that the world only contains animals and partless fundamental particles sometimes called 'simples' or 'elementary particles' (e.g., quarks). The final two sections will pull together the dialectic and explain why, on animalism, we should not be highly confident that the individual that signs an advance directive is identical to the severally demented patient to which it will be applied.

\section{The argument}

Pretend that some time ago I was diagnosed with severe dementia. A disease that progressively eliminates the psychological life of an individual [5]. Years later, there is an individual that I resemble and with whom I might share a history sitting in a chair. The individual is well off considering the circumstances, but lives only from moment to moment with minimal psychological continuity. The individual appears to be me. But is it? Did I survive the devastating loss of psychological continuity? My memories, hopes, fears, interests, and ability to project myself into the future are gone. Am I also gone? More so, the individual in the chair has been diagnosed with pneumonia. Given the mild nature of the infection, the pneumonia is currently treatable, though will eventually be fatal. The individual's cheerful state and the vast monetary resources that pay the medical costs point to not allowing him to die. However, prior to any dementia, I signed an advance directive refusing treatment in the case of such a scenario. Did the individual in the chair sign it? The answer to this question depends on what you think I am and what it takes for such a thing to persist.

So, what does it take for me to persist from moment to moment, month to month, year to year, etc.? Why am I the same thing now that I was when I went to sleep last night and woke up this morning? This is the persistence question of personal identity.

The animalist answer to this question says that I persist if the animal I am persists. I am nothing more than a human animal, an organism, that thing that biology tells us is alive (in the biological sense) that sits in my chair whenever I sit in my chair. On this view the continuation of my beliefs, desires, temperament, personality, memories, etc. have nothing to do with my continued existence. I go where the organism goes. I survive as long as the organism survives, and that survival has nothing to do with psychology 
or anything other than biology. So, I-last-night is identical to I-this-morning if, and only if, the organism is the same organism as it was last night, which is true if the organism survived (remained alive) through the night.

Now, I-as the signee-sign an advance directive in the interest of consenting in advance in case there is a time when I-as the patient-cannot speak for myself in terms of medical treatment. Though not everyone would agree [6], I assume that the consent in this case is binding only if $\mathrm{I}$ am in fact speaking for myself in the future and not someone else. That is, I must be both the signee and the patient for the advance directive to be binding. The signee and the patient must be identical. Imagine that by some bit of philosophical magic you, in a similarly demented state, instantaneously replaced me in the hospital bed. Would my advance directive apply to you just because you were my spatiotemporal descendent? I think not. Not any more than my advance directive would apply to a patient who became associated with my medical records due to a clerical error.

So, what happens if we are unsure of the relationship between the signee and the patient when an advance directive is lethal? Say, you are $60 \%$ confident (40\% uncertain) in your belief that the signee and the patient are identical. Do you let the cheerfully demented patient die of pneumonia? What about a 75\% confidence that the individuals are identical? To help, imagine that Quinn is a patient under your care. You are $100 \%$ confident that Quinn-the-signee is identical to Quinn-the-patient. However, because of the mishandling of some records you can only be $75 \%$ sure that Quinn is in bed 347 and not in bed 348. Patients in both beds are as similar as they can be. Both are cheerfully demented and will die of pneumonia if not treated. However, one of them has an advance directive to not treat in this circumstance, while the other one does not. Do you let the patient in bed 347 die while there is a $25 \%$ chance she is the wrong patient?

I assume that many would agree that such odds render a lethal advance directive non-applicable. I also assume that such individuals should have a similar opinion in the non-identity case. That is, unwilling to apply an advance directive when they are only $75 \%$ confident ( $25 \%$ uncertain) that the signee and the patient are identical.

What percentage of confidence is enough to risk letting the wrong patient die? Rather than answer that question I will refer to such level of certainty as a 'high level of confidence'. We must have a high level of confidence that the patient is identical to the signee of the advance directive that is allowing her to die. Here are other beliefs that I hold with a high level of certainty: that I exist, my name, that I am currently typing on a keyboard, where I grew up as a child, etc. Importantly, noting that I could be wrong about some of these beliefs does not take away from my confidence in them, for I have little or no reason to believe they are wrong.

In light of the above, here is the main argument: (1) the application of a lethal advance directive requires a justifiably high level of confidence that the signee of an advance directive is identical to the patient to whom the advance directive is applied; $(2)$ if we are animalists and the patient is severely demented, then we should not have a high level of confidence that the signee of an advance directive is identical to the patient to whom the advance directive is applied; (3) therefore, if we are animalists and the patient is severely demented, then a lethal advance directive should not be applied.

The argument is valid and premise (1) is being assumed for the sake of argument. That leaves premise (2) in need of defense and elucidation. To defend premise (2) I will need to do two things. First, defend that animalists should not be highly confident in their view. Second, I will need to show that, if animalism is false, then the animalists' likely alternative accounts leave them less than highly confident that the signee and the patient are identical.

\section{The cost of animalism}

Animalism is a materialist view of personal identity (i.e., no part of us is immaterial) in which we are merely animals. Each of us is identical to a human animal (homo sapien) in the same trivial sense that anything is necessarily identical to itself. If this is correct, then I am not merely a brain or some collection of thoughts. I am not something like an immaterial soul, which is intimately related to my animal, but entirely separate from it. I am literally a human organism, a biological object. I survive as long as and only as long as my animal survives because we are the same. I could entirely lose my ability to think, but as long as this does not entail a biological death, I have survived. To be any sort of thinker on animalism is like being a teenager. It is just a phase. It is marked by the having of certain properties at a time. For instance, if I am enrolled in school, then I am a student. Likewise, if I have mental properties, then I am a thinker. If I lose my mental properties I cease to be a thinker but I do not cease to be an animal. The animal is what I am. Being a thinker is just a phase. In fact, if animalism is true, then I plausibly started life as a non-thinker, a zygote, without a brain or an ability to maintain mental activity. The upshot of animalism is that in principle I can lose any property not necessary for biological life and survive.

Eric Olson is the primary defender of animalism, and the Thinking Animal Argument below is his go-to defense of the position [7]:

\section{Consider a situation where you are alone in a room sitting in a chair and thinking...}

A1. There exists a human animal sitting in your chair.

A2. If there exists a human animal sitting in your chair, then that animal is thinking.

A3. If there is a thinking human animal sitting in your chair, then that human animal is you.

A4. Therefore, you are a thinking human animal [8].

The argument is straightforward and cashes in on the materialist conception of mental properties as more or less physical parts of my brain. For most animalists, mental properties are certain neurological states that play the right role. If such neurological states belong to the animal, then, if I am truly alone in the room, and there is an animal thinking in my chair, then I am that human animal. This argument is not unassailable, but is unchallenged in its ability to bring the animalist account of identity on par with other more historically accepted accounts [7].

Here is the problem. Objections to animalism push animalists to adopt beliefs about the world that deny 
commonsense. By 'commonsense' I mean whatever it is that justifies platitudes, propositions that are so prolific and obvious that they need not be supported by argument. For example, I need no argument to support the belief, "The sun will rise tomorrow." It is commonsense. This does not mean it could not be false, but it does mean that it can be accepted without argument. However, as a general rule, if enough beliefs from a particular source are found to be mistaken, then we should no longer trust that source. Likewise, if we deny too many commonsense beliefs, then a belief's being commonsense ceases to be a good reason to believe it is true. Finally, if for some reason the term 'commonsense' troubles you, then replace it with whatever you take to justify platitudes and the substance of my argument will remain unchanged.

Premise (A1) of the Thinking Animal Argument is prima facie justified by commonsense. The same commonsense that tells us that tables and chairs exist. However, the animalist in defense of her position denies the existence of all ordinary objects such as, tables, chairs, lampposts, coffee, livers, brains, etc. The only exceptions are animals like starfish, quail, dogs, cats, pandas, you, me, etc. Such a systematic denial of commonsense belief is good reason to strongly doubt other related beliefs. Thus, if we can no longer trust our commonsense about ordinary objects, then we should also doubt our commonsense about the existence of animals. After all, animals are just ordinary objects. In the words of Dean Zimmerman, "The premise [A1] is warranted by its platitudinous or commonsensical status; but Olson's arguments lead him to conclusions that undermine the family of platitudes to which it belongs." [9, p. 23].

So, why must animalists deny the existence of ordinary objects? Well, because the cost of acceptance of ordinary objects is greater than the cost of denial. If human animals have parts with too much potential for thought, then the thinking animal argument can be exploited in such a way that it makes animalism absurd. This exploitation comes in two forms: (i) the rival-candidate objection; (ii) the problem of too many thinkers.

The rival-candidate objection considers other options than the human animal for what might be thinking in the chair in Olson's argument. The objection alters the thinking animal argument's conclusion that I am a human animal by replacing 'animal' with other nouns like 'brain'. This exploits the form of the argument arguing for rivalcandidates as the thinker instead of the animal. If I am alone in a room sitting in a chair and thinking, then I am whatever is in my chair and thinking [7]. For example,

B1. There exists a brain attached to an animal in your chair.

B2. If there exists a brain attached to an animal in your chair, then that brain attached to an animal is thinking. B3. If there is a thinking brain attached to an animal in your chair, then that brain attached to an animal is you. B4. Therefore, you are a thinking brain attached to an animal [8].

Olson disagrees with (B1) believing that the human animal is what's thinking in his chair; the subject of his thoughts. However, what if instead of the human animal a brain is thinking instead and is the subject of my thoughts?
Certainly, if I am anything, then I am the subject of my conscious thoughts, but which subject? If there is some object that is thinking instead of the human animal, then the form of the thinking animal argument can be leveraged to show that I am that object, instead of the human animal.

Importantly, for the rival-candidate objection to be successful, one and only one candidate must come out as thinking instead of the animal. For instance, if one believes that the animal's brain is the thinker, and the proper subject of the argument, then she must also deny that the animal's head or the animal itself is a thinker. She must hold that only the brain is thinking. Otherwise, the third premise, "If there is a thinking $x$ sitting in your chair, then that $x$ is you,'" would be false. If we assume that I am the thinking brain but that the animal is also a thinker, then there would always be at least two thinkers in my chair. Thus, if a thinker is in my chair, then that thinker may or may not be me.

Furthermore, if more than one candidate can be identified as the thinker, then the problem of too many thinkers is invoked. That is, there would be more than one thinker literally thinking your thoughts. In this case any more than one thinker is too many. However, if the animal is thinking in virtue of its brain, then how do we understand 'in virtue' in a way that does not entail that brain is also thinking? Or, if we do assume that the brain is thinking, then is there a way to do this and deny the animal thought? If not, then there will be at least two thinkers, which is one too many. Olson puts this problem well:

Consider your head. Your head isn't you: it is smaller than you are. Yet, it has a brain and is hooked up to a nervous system and sense organs just like yours. It interacts with a surrounding community of thinkers and speakers, has an appropriate evolutionary history, and so on. It would presumably be able to think if the rest of you were cut away. Should not that make it rational, intelligent, and self-conscious even now [10, p. 190]?

Any part of my body that includes the brain could replace "head" in the above quote and yield the same result. The area from my hips to my head is part of my body, so is my body minus my pinky. Both of these parts include my brain, and thus would both seem to be "rational, intelligent, and self-conscious even now." [10, p. 190]. So, there are as many thinkers as there are parts of me that include my brain; that is, there are too many thinkers.

Some have avoided too many thinkers by denying that the animal or any part of the animal other than the thinking-part of the brain is a thinker. This is the position of the embodied mind account. Jeff McMahan and Derek Parfit have hypothesized that we are the conscious parts of the brain, those neurological states that produce conscious self-awareness, or at least would be able to with the proper support (e.g., the organism's normal life processes or medical intervention of some variety) $[6,11]$. We are not animals, we are those parts of animal's brain that have a capacity for consciousness.

Unfortunately, it is not at all clear that this does anything to avoid the problem of too many thinkers. Perhaps having a thinking brain is not enough for the animal to be a thinker in its own right. And, this does avoid any part larger than the brain from being an extra thinker thinking my thoughts. But, 
if this region of the brain that could support consciousness could have parts sufficient to be thinkers on their own, then the problem animalists have with brains is still present with smaller-than-the-whole portions of the embodied mind.

Consider the embodied mind Joan-Eunice Smith. She is composed of a complex assortment of brain tissue with a capacity for consciousness. Joan-Eunice has two large parts of her brain called 'Joan' and 'Eunice'. These parts together make up all of Joan-Eunice Smith and mostly overlap each other with the exception of a few cells. As such, each has enough potential for conscious to be an embodied mind very much like Joan-Eunice. Question: are Joan and Eunice both currently embodied minds? They each have the relevant potential for consciousness, so what reason do we have to believe that they are not each embodied minds like JoanEunice Smith? Should we believe that being parts of a larger mind overrules what would otherwise be sufficient for being a thinker? Rather it seems that these parts of Joan-Eunice Smith are (reusing Olson's quote from above), "rational, intelligent, and self-conscious even now"' [10, p. 190].

David Hershenov has further developed this problem for embodied mind account as inspired by medical cases of overlapping cerebra [12]. What the literature calls 'cephalothoracopagus' [13]. Imagine two individuals born attached at the brain. Together their brains compose a large abnormally shaped collection of neurons with a shared portion in the middle. This is analogous to Highway 64 and Broad Street, which occupy the same physical stretch of a road for a time before they eventually diverged at the edge of town. Now, Hershenov asks us to imagine what would happen if a natural disaster wiped out the non-overlapping portions of Highway 64 and Broad Street. It seems that, although they now entirely overlap, there are still two distinct roads. With this in mind Hershenov says:

Assuming that brains can be reduced in size like roads, then if roads can come to completely overlap, brain-size persons should be able to as well. It would be arbitrary to insist that one person survives and not the other. But it is unappealing to claim that a new person fuses into existence for this isn't a case of two objects merging their matter and forming a larger entity. Rather, this just involves someone losing parts of their anatomy that we would uncontroversialy deem the shrinking of a person in the absence of overlap. So, it seems that even McMahan and Parfit would have to admit that two thinkers can come to have their thoughts generated by exactly the same neurology [13, p. 207].

If Hershenov is right, then if Joan-Eunice were to lose enough cells as to be paired down to just the Joan part or just the Eunice part, then Joan, Eunice and Joan-Eunice would all three occupy the same physical space. To deny this is to deny that I could survive getting smaller by losing a handful of cells in my brain; presumably even as an embodied mind I would regularly gain and lose parts. Like the case of the roads, we lack a principled reason to deny that all three, Joan-Eunice, Joan, and Eunice survived and now occupy the exact same physical space due to what appears to be a normal loss of parts. If I am an embodied mind rather than an animal, I still might be sharing my thoughts with other thinkers. Thus, the embodied mind account does not offer an easy solution to the problem of too many thinkers. In fact, any view that allows the thinker to have parts that are on their own sufficient for consciousness will have these same problems [13].

The animalist has a solution. One that has been adopted by at least one embodied mind theorist as well [14]. It is elegant but costly; it is to deny the existence of brains and parts of brains - to deny that rival-candidates exist. This is a metaphysical solution in which one adopts an ontology where undetached parts (brains, parts of brains, etc.) do not exist. If one principally makes this denial it is hard to not also deny the existence of most everyday objects-thus, if you are an animalist, then you might escape these objections by revising your ontology of objects, but then you must have also denied that there are any everyday objects other than animals.

This is called 'biological minimalism'. It affirms the existence of only animals and simples. Chairs do not exist; rather there are only simple particles arranged in the shape of a chair. Adopting this view aids the animalist in handling rival-candidate and too many thinker type objections by eliminating any part of me large enough to be a rivalcandidate thinker.

Biological minimalism arises from reflections on the special composition question: under what circumstances is some object composed by other objects as its parts? Van Inwagen's proposed answer to that question is that some object has parts only and always when the parts are caught-up-in-the-life of the object [1]. Roughly, to be caught-up-in-a-life is to be engaged in those activities that constitute an organism's biological life. Accordingly, something has parts only if that thing is an organism and the parts are caught-up-in-the-life of the thing. Everything else must be entirely simple (i.e., entirely lacking of parts). Brains, kidneys, lampshades, books, and watches, have parts if they exist, but are not organisms. Thus, biological minimalism says they do not exist but are mere arrangements of simples. So, it goes for all other complex non-organisms; they do not exist. Fundamental particles (the most basic unit of a physical theory) on the other hand might be simple. In which case they could exist and not be organisms. So, if biological minimalism is true then the world is filled with simples, the organisms whose lives in which they might be caught up, and nothing else.

Biological minimalism gets the animalist what she wants by sacrificing commonsense about ordinary objects. Commonsense about ordinary objects is what justifies our belief that animals exist. Thus, by undermining commonsense about ordinary objects, our justification for the belief that animals exist is decreased. If animals do not exist, then biological minimalism and animalism are both false. So, as it stands, if biological minimalism is true, then we should be less confident in the truth of animalism, than when we began; and if biological minimalism is false, then the animalist is left with troubling objections to her view. Either way, the animalist has suffered a loss of confidence.

One might hope that the animalist would justify the existence of animals some way other than as a platitude. However, the literature suggests otherwise. The most well developed defenses of animalism by van Inwagen, Olson, and Merricks all, after adopting biological minimalism, justify the existence of animals with something like a commonsense 
inference. Van Inwagen argues that we know that animals exist because you and I exist, the nature of thought requires us to be composite material beings, and animals make the most sense as candidates for such composites [1, p. 122]. Olson, says little more than, composition is plausible, and if there is composition, then animals are composites: "The particles that make up a live cat are unified if any particles are'" [15, p. 114-115]. Merricks, appeals to the fact that animals perform most of the everyday activities that we also perform. When I get out of bed, so does an animal; when I wind my watch, so does the animal. So, if we exist, then we are probably organisms. We exist; thus, so do animals [3, p. 114-115].

The point is not to say that there is something illicit about this style of inference. There is not. Everyone begins with what they take to be plausible assumptions; initial assumptions should seem true (even Descartes assumed, "I think"). Each of these philosophers recognize that philosophical questions are rarely settled by devastating arguments that render the opponent's position incoherent. Rather, questions are answered by considering puzzling cases (e.g., Debtor's Paradox, Ship of Theseus, Body-minus, Problem of the Many, etc.), counting the cost of theories, working with arguments, and finding balance [16].

The point is that the justification for animals in these instances is a product of commonsense about objects and composition. This justification is no longer as strong after denying that most ordinary objects exist. For these arguments to work, it has to be commonsensical for organisms to exist. But, after we adopt an ontology that tells us that there are no tables, chairs, brains, fingers, lemonade, or cupcakes, but rather just particles arranged as such, our reasons for believing that organisms exist, and are not themselves just clouds of particles, is reduced.

What drives commonsense as an arbiter of belief is that there is a cost to assuming false what is easy to believe, hard to deny, and possibly widespread. Some beliefs are innocent until proven guilty. For instance, my having hands, that there is an external world, that I am identical to the person I was 20 years ago, etc. are all commonsense. It is rational to have such beliefs until they are undermined or defeated, and that is because denying them comes at the price of rendering the world very different than what some of our most strongly held commonsense beliefs tell us. However, if it can be shown that the price of denying a strongly held commonsense belief is acceptable or has already been paid through the reasonable adoption of some unintuitive theory, then commonsense is no longer as strong a source of justification.

This creates two issues for the animalist: (i) if you have accepted a sparse ontology, then you have already paid the price of denying commonsense about ordinary objects, including animals; (ii) the loss of commonsense as justification for the existence of animals makes it harder to accept animals as what I am over and above a psychological account, which can do without animals or composite objects.

What is commonly called 'neo-Lockeanism' is concerned with connections between psychological states (i.e., memories, desires, personality, etc.). You are your psychology; you are a chain of psychological states-no animals required. As long as the chain is sufficiently unbroken, then you continue to exist $[6,17]$.

The first issue has already been explained above. In summary, the price of denying commonsense, is a function of rendering nearly all beliefs about ordinary objects false; my justification for believing in chairs and tables was platitudinous. I saw them every day and had no reason to doubt their existence. This is also largely why I believed in animals, so now I need more to justify belief in their existence.

The second issue is that after lowering justification in the existence animals, the rival-candidate objection can once again be raised. A chain of psychological states being the rival-candidate. Initially it seemed that on biological minimalism, any candidate for what I am other than the animal would be sufficiently counter intuitive as to not be a true rival-candidate. However, as demonstrated above animals no longer have a privileged place as the commonsensejustified option for what I am, and thus, the "there is an animal" portion of premise (A1) of the Thinking Animal Argument needs more than platitude-status to be taken as true.

The psychological account now looks more attractive. We have already admitted that we are struggling to keep animals in our ontology. To wit, eliminating animals can be seen as a feature and not a cost of a view. The fact that psychological-persons could explain what we are without identifying us with animals is a problem for the animalist.

After all, what reason do we have that animals, or any other composite thing, exists? The reason given was that, "I am a composite object!" and something like the thought, "If it were the case that animals did not exist, then it would be unclear what I am." Consider Olson and his remarks about non-animalist options for what we are, "For those who enjoy metaphysics, these are all fascinating proposals. Whatever their merits, though, they certainly are strange. No one but a philosopher could have thought of them. And it would take quite a bit of philosophy to get anyone to believe one of them. Compared with these claims, the idea that we are animals looks downright sensible"' [10, p. 200]. It is agreeable that, if it is prima facie true that "I think" and that animals exist, then the Thinking Animal Argument has purchase. However, after the animalist faces objections and adopts biological minimalism, it is no longer prima facie true that animals exist. At this point, one cannot posit the existence of animals without evidence, and that I exist and seem to be a composite is not as convincing as it was prior to taking a hard look at biological minimalism.

I gather the animalist must now first raise arguments against the psychological criterion before even assuming the existence of animals. Prior to adopting biological minimalism, one could have objected to the suggestion of psychological-persons citing organisms as a better candidate for what is in my chair and thinking: "It makes more sense!" However, now there are no tables, chairs, heaps, or ships of Theseus; there are also no brains, or livers, you do not have hands and apple trees do not have apples. The qualitative count on biological minimalism is minimal, and most (principally held) beliefs about everyday objects (that I have had most of my life) are false. I believed in chairs, rocks, and tables, because I see them every day; they were hard to deny, and now merely seeing "animals" all around me does 
not help me decide what is sitting in my chair, especially if there are other (perhaps) serviceable options.

\section{A loss of confidence}

As I sit here, I find myself believing that there is a mug of coffee sitting on my desk. However, if I am an animalist, then I should not believe this. This is relevant because it extends to the existence of animals as well. They are after all ordinary objects, with their existence justified by commonsense, or whatever it is that justifies platitudes. If I am an animalist, then I must believe that animals exist. Thus, if I have a lowered confidence in the existence of animals, then I have a lowered confidence in my belief that animalism is true.

This is no great loss to the animalist, per se. It hardly makes for a convincing argument against the position. After all, metaphysics is a speculative enterprise. However, the considerations of the previous section aim to highlight exactly the cost of being an animalist, and to what extent I should be confident in its truth.

This is important because, in so much as I am not confident in animalism, I should not be confident in those beliefs I justify based on the truth of animalism. One such belief is that, I survive as long as my organism, the organism that I $a m$, survives. This in turn has the consequence of justifying the belief that, I can survive a transition into a severally demented state via organismic continuity. Thus, if I believe that animalism is true, then I have reason to believe that the signee of my advance directive and the patient it would be applied to are identical. So, I contend that with a loss of confidence in animalism, I suffer a loss of confidence in the signee and the patient's being identical, in cases of severe dementia. Mind you, it may very well be just a loss of confidence. I might still believe they are identical, but my certainty is not what it was prior to defending animalism.

Let us take stock of how the discussion up to this point supports the second premise from the main argument. The premise states:

(2) If we are animalists and the patient is severely demented, then we should not have a high level of confidence that the signee of an advance directive is identical to the patient to whom the advance directive is applied.

To defend this claim I needed to show two things: (i) the animalist should not be highly confident in their view; (ii) if animalism is false, then the animalist's likely alternatives leave her less than highly confident that the signee and the patient are identical. I have argued for the former by showing the justificatory cost of adopting a sparse ontology. The latter will be argued below.

What about alternatives to animalism? I will consider the two that I take to make up the bulk of the bioethics literature: the psychological account and the embodied mind account [6]. If neither of these accounts grant a high level of confidence in the identity of the patient, then we can conclude that for a significant number of animalists, by lowering confidence in animalism, we raise uncertainty that the patient is identical to the signee.

Here is why. We are assuming that if animalism is false, then we lose justification for the belief that the signee and the patient are identical. However, if the likely alternatives to animalism also supply high-confidence justification for the belief that the signee and the patient are identical, then the falsity of animalism would not necessarily entail a net loss of justification. Rather the justification from animalism might merely be exchanged for the justification of another view. So, if by reducing confidence in animalism we raise confidence in another view, then we have to check and make sure that we are not just replacing the justification of animalism with the justification of some other view-in this case, that of the psychological account or the embodied mind account. So, what is needed is for the relevant alternative accounts to supply less than high-confidence justification for the belief that the signee and the patient are identical, and thus for there to be a net loss of justification in the case that such an account replaces animalism. A full discussion of this issue would also include the constitution view, hylomorphism, soul theory, and all of those views' various iterations. I assume that no matter how well argued for these positions may be, the psychological account and the embodied mind account are popular enough as to yield a significant conclusion without considering other views.

Alright, the psychological account requires that for identity to obtain between the signee and the patient they be psychologically connected to one another. Necessary for psychological connectedness is the having of veridical memories that were caused in a normal way. If I continue from day to day, then I must have memories that stretch into the past connecting me in a sense to my past selves. These memories must be about events that actually occurred and cannot have been planted by an evil scientist or otherwise fabricated [16]. Importantly, the connection cannot have gaps. If there is a gap, say a time when an individual permanently lost all memories due to a head injury, then identity is not preserved over the gap. Memories are among the psychological features that are destroyed as dementia progresses, which gradually destroys psychological capacities generally. In the case of severe dementia not only might a patient not remember signing an advance directive, they may have no memories from earlier in the day. Thus, according to the psychological account, such a patient might not just be nonidentical to the signee, but non-identical to the individual who was sitting in their chair hours before [6].

The problem of identity is also found on the embodied mind account. Rather than relying on psychological connectedness, this account tracks identity by the continuing of those parts of the brain with a capacity for consciousness. Initially McMahan seems to deny any problem of identity on his account, "According to the embodied mind account of identity... there are no cases in which progressive dementia results in a different individual, much less a different person." However, he continues, "perhaps it would be more accurate to say that there is no new or different individual. For what remains may not in any robust sense be the same individual but merely a fragment of that individual... It is possible to see this process as the gradual fading from existence of the individual himself', [6, p. 494]. McMahan seems to consider his account a solution to the problem of identity and advance directives, but then suggests that what is left of the individual might be vague and come in degrees. So I ask, to what degree must I exist as the patient for the advance directive I signed to still be binding? If it is entirely indeterminate whether I still exist, then is an advance 
directive sufficient to allow the patient to die? Without answering these questions, we can conclude that we should, at least, not be highly confident that the signee and the patient are identical, which is what is required for premise (2).

To conclude, when allowing someone to die, we should be highly confident that we are letting the right individual die. In the case of advance directives, that individual is the one who signed the lethal advance directive. Animalists, when dealing with the severely demented, should not be highly confident; if animalism is false, then relevant alternative accounts should render us less than highly confident in the identity of the signee and the patient. It follows that the extent to which we should not be highly confident in animalism, is, at least, the extent to which we should not be highly confident in the identity of the signee and the patient. As has been argued, no one should be highly confident in animalism.

\section{Disclosure of interest}

The author declares that he has no competing interest.

\section{References}

[1] Van Inwagen P. Material beings. Ithaca: Cornell University Press; 1991.

[2] Olson ET. The human animal: personal identity without psychology. Oxford: Oxford University Press; 1997.
[3] Merricks T. Objects and persons. Oxford: Clarendon Press; 2001.

[4] Hershenov D. "Do dead bodies pose a problem for biological approaches to personal identity?". Mind 2005;114(453):31-59.

[5] Firlik AD. "A piece of my mind. Margo's logo". JAMA 1991;265(2):201.

[6] McMahan J. The ethics of killing: problems at the margins of life. New York: Oxford University Press; 2002.

[7] Olson ET. What are we? A study in personal ontology. New York: Oxford University Press; 2007.

[8] Olson ET. "An argument for animalism". In: Martin R, Barnes J, editors. Personal identity. Oxford: Blackwell; 2003. p. 318-34.

[9] Zimmerman D. "Problems for animalism". Abstracta, Special 2007;1:23-31.

[10] Olson ET. "Thinking animals and the reference of 'l"', Philos Top 2002;30(1):189-207.

[11] Parfit D. We are not human beings. Philosophy 2012;87(01):5-28.

[12] Hershenov D. Who doesn't have a problem of too many thinkers? Am Philos Q 2013;50(2):203.

[13] Biswas A, Chia D, Wong Y. "Three-dimensional sonographic diagnosis of Cephalothoracopagus Janiceps twins at 13 weeks". Ultrasound Obstet Gynecol 2001;18(3):289-90.

[14] Dowland SC. "Embodied mind sparsism". Philos Stud 2016;173(7):1853-72.

[15] Olson ET. "Replies". Abstracta, Special 2008;1:32-42.

[16] Cannon MR, editor. Material constitution: a reader. Lanham: Rowman \& Littlefield; 1997.

[17] Parfit D. Reasons and persons. Oxford: Oxford University Press; 1984. 